\title{
THE CHALLENGE OF SUSTAINABLE DEVELOPMENT
}

\section{Godfrey Baldacchino}

This paper seeks to put into a proper policy perspective the current 1 discussion on the attraction of 'sustainable development'. This is attempted by forcing an application of the often rhetorical nature of the argument and thus exposing the difficulties, particularly those of a political and socio-cultural nature, which impinge on the theme. These may inhibit what looks like a universally desirable policy option from coming into action. Reference is made to the peculiar circumstance of Malta, suggesting that implications of the concept are of even greater relevance to our own country. Yet, such a local realization is socially still far from visible in this present day and age.

\section{Defining the Jargon Phrase}

For a decade green has definitely been the world's political colour. ${ }^{1}$ In this context a new jargon phrase is being tossed about in the mass media and various policy documents: Sustainable Development. It stems from a concern that many activities undertaken in the name of development have actually squandered the (often finite) resources upon which development is based. In the industrialized countries, the rapid consumption of natural minerals, such as fossil fuels and metals, is a major concern, while in the least developed countries over-exploitation of natural biological assets is usually the major threat to sustainability.

Definitions of 'sustainable development' usually talk of improving people's material well-being through the utilization of the Earth's resources but at a rate that can be sustained, at least over many decades, but preferably indefinitely. A definition which has achieved wide currency speaks of a 'development that meets the needs of the present without compromising the ability of future generations to meet their own needs'. ${ }^{2}$ Sustainable development is a situation in

1. The Economist, 15 October 1980.

2. World Commission on Environment and Development, Energy 2000: A Global Strategy for Sustainable Development (The Brundtland Report), London, 1987.

Hyphen - Vol VII. Number 1 
which the development vector (which may include such elements as real income per capita, health and nutritional status, educational achievement, access to resources, basic freedoms,...) does not decrease over time. ${ }^{3}$

The basic idea could not be simpler: to live off nature's interest rather than depleting its capital.

\section{Documenting the Ills}

The problems associated with irresponsible resource consumption have been documented ad nauseam by various concerned organizations and individuals, so much so that some of the key arguments appear to have successfully filtered down to the mindframe of the public at large: in the advanced industrialized economies of the North, chemical pollutants and high levels of combustion lead to acid deposition, air and water pollution, lead poisoning. Military expenditures are major culprits of resource misallocation. In the still developing South, the main environmental costs are usually associated with degradation of the natural resource base - deforestation, soil erosion and the dumping of toxic wastes are occurring at alarming rates. And when rural livelihoods are undermined, people migrate to the cities, where inadequate water and sewage services, and the degraded sites on which the poor are forced to live, pose other environmental problems. Not to mention the sinister consequences of global warming and ozone depletion, which do not discriminate between first-world and third-world candidates.

\section{Identifying the Debate}

The adherents of sustainable development challenge the very foundation of the mainstream interpretation of the development problem. They question the fundamental assumptions of both neoclassical 'modernization' approaches to development, ${ }^{4}$ as well as the more radical neo-Marxist structuralist critiques of

3. Pearce, D. et.al., Sustainable Development: Economics and Environment in the Third World, London, 1990.

4. See, for example, Lewis, W.A., The Theory of Economic Growth, London, 1955; Rostow, W.W., 'The Take-Off into Self-Sustaining Growth', Economic Journal, Vol. 66 (1956), No. 1, pp. 25-48; Galbraith, J.K., The Afflueñt Society, London, 1958; Friedman, M. \& R. Friedman, Free to Choose: A Personal Statement, Harmondsworth, 1980. 
underdevelopment. ${ }^{5}$ In spite of their glaring differences, both of these perspectives take for granted the production of more and more consumer products as synonymous with development. This approach is claimed to be not only wasteful but also worsens the long-term prospects, and the very life-chances, of future generations, especially among the poor.

The policy implications are crude and shattering: consume/produce less and differently and move from a consumer to a conserver economy, where production, growth, and conservation are not mutually exclusive. ${ }^{6}$ Critics nevertheless argue that this kind of approach is unacceptable because it constitutes in effect a preindustrial 'back-to-nature' condition which is equivalent to a rescinding, not a reformulation, of development.

\section{Between Rhetoric and Practice: the Great Divide}

Few would contend that sustainable development is now a pervasive buzzword, even in the circuits of policy rhetoric. The term, however, is not so readily operationalized and enshrined into real-life projects. A significant issue here is the question of interest promotion and preservation. The process of rapid industrial development which has triggered the reactive outcry for sustainability has also served to consolidate the economic significance and (in consequence?) the political power of a number of interest groups in society. Indeed, the rationale behind rapid industrialization is often couched in terms of the vastly improved benefits which accrue to large sections of the community: lucrative and steady profits to investors, taxes to the state, mass jobs to the workers, cheap and plentiful products to consumers,.... The beneficiaries of industrialization will not be easily

5. Amin, S., Accumulation on a World Scale, Volumes 1 \& 2, London, 1974; Baran, P.A., The Political Economy of Growth, London, 1957; Wallerstein, I, The Capitalist World Economy, Cambridge, 1979.

6. There is today a modest corpus of literature which proposes a green perspective to development. These include Ekins, P. (Ed.), The Living Economy: A New Economics in the Making, London, 1986; Galtung, J. Development, Environment and Technology: Towards a Technology for Self-Reliance, New York, 1979; WorldWatch Institute, State of the World, New York, WWI (annual); Dag Hammarskjold Foundation, Another Development: Approaches and Strategies, Uppsala, 1977; Daly, H.E. (Ed.), Towards a Steady-State Economy, San Francisco, 1973; Reid, W.V.C., 'Sustainable Development: Lessons from Success', Environment, Vol.31 (1989) No. 4, pp. 6-9; World Resources Institute, The Global Possible, Washington DC, 1984. 
dislodged from the privilege of enjoying what has now become more than simply a way of life, but, in many respects, the only feasible one.

In the North, many are unwilling, or perhaps even unable, to envisage a life without so many presumed necessities: concern for sustainable development is tantamount, in their eyes, to a radical and therefore unacceptable reduction in one's standard of living. In the South, there is mounting suspicion that sustainable development is nothing but a respectable facade for the thwarting of third-world development. The First World has had its industrial field day. Now, with signs that its competitive edge is being eroded, the sustainable development argument being put forward may yet help to preserve Western ascendancy. The South appears just as determined as the North to reap the benefits of industrial development, regardless of the associated environmental costs. It seems that the environmentally harmful side-effects of industrialization pale into insignificance in contrast to the resulting growth and prosperity. The prophets of doom and gloom would no doubt be silenced once again as industry itself matures and conjures up new techniques and technologies with which to postpone the fateful appointment with ecocatastrophe. ${ }^{7}$ Far better, therefore, to taunt the distant spectre of maldevelopment than to stem the clamour by growing proportions of populations for the consumer goods produced by the technology of the industrial society.

Certain Third-World radicals actually denounce the tenor of the current eco-debate, accusing it as being mainly ethnocentrist and elitist by virtue of having depoliticized the character of the conflict in the world between the haves and the have-nots by magnifying the contest between man and nature. ${ }^{8}$ The remedy for the growing international conflict and tensions, they claim, lies in tackling its root cause, namely, the global inequality and oppressive and exploitative institutions which impose and perpetuate the malaise.

\section{A Local Perspective}

It appears only a question of time before Malta finds itself locked in the throes of this debate. Some of the reasons behind this personal

7. Bahro, R., Socialism and Survival, London, 1982 Books; Meadows, D. et.al., The Limits to Growth, Washington DC, 1972; Mesarovic, M. \& E. Pestel, Mankind at Turning Point, London, 1975.

8. Lal, S., Third World Attitudes and Atmospheric Environment, Oxford, 1973. 
prognostication are obvious, others not so. Malta is first of all a developing country with a still young history of political sovereignty. It therefore faces the tempting option of adopting a rampant industrialization strategy as a development option. This Malta has done over the last thirty-odd years with a certain commendable momentum, achieved and maintained thanks to a repertoire of adequate incentive provisions to foreign investment accompanied by a convenient and attractive geographical position, close to the largest market in the world. Its traditional role as a strategic fortress economy in the Mediterranean, with the inculcation of various industrial skills which that implied, provided the country with a flexible workforce trained in basic technical expertise and routines, a useful advantage in trying to entice foreigners to set up shop locally.

The second reason behind Malta's imminent engulfment in the sustainable development debate is related to its social-economic status as a developing post-colonial microstate. The country is one of around three dozen sovereign states in the world today which have a relatively small territorial size. In spite of having low population levels in absolute terms, the territorial limitations of these very small hence micro - developing states create an even stronger pressure on already scarce resources. The population densities are thus typically higher than would be expected, and these can be exacerbated by the relatively high proportion of unexploitable land area due, for example, to desert, dumping of waste, flooding, or high tide.

Malta shares with these countries an intensification of the problem of the management of space which is a most precious resource. Such microstates can be considered as laboratory test-cases which allow one to examine the effects of rampant industrialization and of the policy decision and outcomes of the powers-that-be in trying to come to terms with the tensions of development and environmental preservation. These countries could serve as advance warnings of undesirable scenarios. Already, the archipelagic reef microstate of Tuvalu in the Pacific Ocean is an unwilling prime candidate for the catastrophic effects of global warming; it will disappear quietly beneath the waves owing to sea level rise unless the causes behind global warming are halted and preferably reversed. ${ }^{9}$

9. Lewis, J., 'Sea-level Rise: Some Implications for Tuvalu', Paper presented at the Conference on Small Island Development, Valletta, Malta, Foundation for International Studies, 24-28 March 1990. 


\section{A Necessary Sacrifice?}

Is this the shape of things to come? Will the errors of microstates serve to illuminate and educate wiser, larger neighbours whose size and scale can afford them to experiment without experiencing shattering, devastating side-effects? Will the microstates suffer the consequences of non-sustainability and will their noble sacrifice be a necessary demonstration effect to stave off similar disasters elsewhere? One may dread to think in these terms, but the questions are not altogether fictitious and fanciful ones. The Tuvaluan case may seem far-fetched and remote; but consider our own unfolding story of 'development' and its costs. The dedication of so much land area to industrial sites; the burgeoning volume of traffic; the debate on the building of the new power station at Delimara; the problem of waste disposal and sewage treatment; the contraction of fertile agricultural land; and so on.

The problem is not simply one of finite and scarce resources available for exploitation; it is compounded by the wide distribution of nearcontinental consumption values. Our cultural identification with the Western world leads so many of us to strive for luxury goods and behaviour patterns the country can ill afford. Policy makers, locked in the democratic framework, appear powerless and cannot but ventilate and provide still wider opportunities for conspicuous consumption to try and ensure their own political survival. Apart from attempts at environmental education, there are few viable and not politically suicidal devices at hand to restrain such a rampant cultural phenomenon. As the Premier of another micro-territory aptly put it: 'We are a bicycle society with Cadillac tastes. ${ }^{10}$

\section{The Hidden Salvation of Tourism?}

Perhaps we have all too readily embraced the advantages of industrial development without assessing its negative side-effects. In a way, our option for tourism - an option which most microstates have taken up successfully but initially on a 'second-best' basis - may be a blessing in disguise, since this tertiary sector activity, unlike mass machinofacture, has a stake and a much more active interest in preserving the environment. Tourism, for all its limitations, may be

10. The statement was made in the 1960 s by the Premier of Montserrat, a Caribbean island with a population of about 14,000 and still a British Colony. 
more attuned to the principles of sustainability. ${ }^{11}$ It is also mercifully exempt from the iron logic of economies of scale.

Malta has taken commendable initiatives on the world stage in favour of environmental preservation. ${ }^{12}$ It would be bitterly ironic, apart from tragic, were it to end up as an exponent of how not to develop...

11. For example, Connell, J., 'Sovereignty and Survival: Island Microstates in the Third World', Research Monograph No. 3, (1988) Sydney, Department of Geography Australian National University.

12. These include the Concept of the Climate as Common Heritage of Mankind and the United Nations Law of the Sea (UNCLOS).

GODFREY BALDACCHINO, MA, PGCE, MA (The Hague) is Research Officer at the Workers' Participation Development Centre (WPDC) and Tutor in Labour Studies at the University of Malta. He is currently a Ph.D. candidate at the University of Warwick, U.K. 